\title{
Soil carbon stock in different uses in the southern cone of Mato Grosso do Sul
}

\author{
Luis Felipe Batista Nandi Martins', Douglas Troian', Jean Sérgio Rosset ${ }^{1}$, Camila Beatriz da \\ Silva Souza ${ }^{1}$, Paulo Guilherme da Silva Farias ${ }^{1}$, Jefferson Matheus Barros Ozório ${ }^{1}$, Leandro \\ Marciano Marra', Selene Cristina de Pierri Castilho ${ }^{1}$
}

\begin{abstract}
${ }^{1}$ Universidade Estadual de Mato Grosso do Sul, Unidade Universitária de Mundo Novo, Mundo Novo, Mato Grosso do Sul, Brasil. E-mail: luisfelipegambiental@hotmail.com,douglas_igt95@hotmail.com,rosset@uems.br, camilabeatrizss@hotmail.com, pauloguilhermesf@hotmail.com,ozorio.jmb@outlook.com, marra@uems.br, selenecastilho@uems.br
\end{abstract}

Received: 23/07/2020; Accepted: 27/09/2020.

\begin{abstract}
This study aimed to assess the soil density $(\mathrm{Sd})$ and the total organic carbon contents and stocks in different management systems and implementation times in the municipality of Iguatemi, MS, Brazil. A completely randomized design with four replications was applied to four areas: conventional tillage (CT), reformed pasture (RP), and degraded pasture (DP), in addition to a native forest (NF) area with no anthropic action. Disturbed and undisturbed soil samples were collected at depths of $0-0.05,0.05-0.1$, and $0.1-0.2 \mathrm{~m}$. The determination of Sd and total organic carbon content (TOC) allowed calculating the carbon stock (Cstock), the stratification index (SI), and the carbon stock variation ( $\Delta$ Cstock), with subsequent multivariate analysis. The NF area presented the highest TOC contents at all depths compared to the managed areas, with a value of $17.45 \mathrm{~g} \mathrm{~kg}^{-1}$ at a depth of $0-0.05 \mathrm{~m}$. The RP and NF areas showed similar SI, which was higher in PD, with a value of 2.54. Except for RP, the other managed areas showed a negative $\Delta$ Cstock in the soil profile relative to the NF area. The RP and NF areas promoted the maintenance of TOC in the soil, while DP and CT compromised the edaphic quality.
\end{abstract}

Keywords: soil quality, soil organic matter, principal component analysis, pasture management.

\section{Estoque de carbono do solo em diferentes usos na região cone-sul de Mato Grosso do Sul}

\section{RESUMO}

O objetivo deste trabalho foi avaliar a densidade do solo (Ds), os teores e estoques de carbono orgânico total em diferentes sistemas de manejo e tempos de implantação no município de Iguatemi, MS. Foi utilizado o delineamento inteiramente casualizado com quatro repetições, sendo estudadas quatro áreas: lavoura em sistema de preparo convencional (PC), pastagem reformada (PR) e pastagem degradada (PD), além da área de mata nativa (MN) sem ação antrópica. Foram coletadas amostras deformadas e indeformadas de solo nas camadas 0-0,05, 0,05-0,1, 0,1$0,2 \mathrm{~m}$. Foram determinadas a Ds e os teores de carbono orgânico total (COT), sendo calculado o estoque de carbono (EstC), o índice de estratificação (IE) e a variação do estoque de carbono ( $\triangle$ EstC). A área de $\mathrm{MN}$ apresentou, em todas as camadas, os maiores teores de COT em relação às áreas manejadas, apresentando teor de $17,45 \mathrm{~g} \mathrm{~kg}^{-1} \mathrm{na}$ camada de 0-0,05 m. As áreas de PR e MN apresentaram IE semelhantes, porém, na área de PD o IE foi superior, com IE de 2,54. Com exceção da área de PR, as demais áreas manejadas apresentaram $\triangle E$ EtC negativa no perfil do solo em relação à área de MN. A PR e a MN promoveram a manutenção do COT no solo, por outro lado, a PD e o PC comprometeram a qualidade edáfica.

Palavras-chave: qualidade do solo, matéria orgânica do solo, análise de componentes principais, manejo de pastagens. 


\section{Introduction}

Soil quality (SQ) is related to the soil capacity in maintaining ecosystem services, including storing and recycling water, nutrients, and energy (Doran and Parkin, 1994). One of the main soil potentials is to store carbon (C), with direct influence on its chemical, physical, and biological quality (Koven et al., 2017; Assunção et al., 2019; Ferreira et al., 2020; Rosset et al., 2019; D’Abadia et al., 2020; Falcão et al., 2020; Ozório et al., 2020). However, changes in the soil $\mathrm{C}$ content are directly related to changes in land use, affecting this important natural C reservoir on the planet (Lal, 2018; Wang et al., 2019).

Possible changes in land use in native or cultivated areas can be studied through quality indicators (Corbeels et al., 2019). Soil organic matter (SOM) is a sensitive indicator of soil changes resulting from its use and occupation. Carbon stock, C fractions, and soil chemical, physical, and biological attributes are closely related (Signor et al., 2018).

Organic $\mathrm{C}$ in soils with natural vegetation cover is in dynamic balance, with practically constant contents over time (Borges et al., 2015). The understanding of the dynamics and accumulation or not of $\mathrm{C}$ in managed and natural systems allows supporting the establishment of management strategies that guarantee an increase in MOS content and an improvement in the environmental and soil quality over time (Rosset et al., 2016; Assunção et al., 2019; Ferreira et al., 2020; Nijmeijer et al., 2019).

Agricultural cultivation systems managed incorrectly, especially with intense disturbance, such as the conventional tillage (CT) system, provide a reduction in the edaphic quality, with a reduction in carbon contents (Sarker et al., 2018) and stocks (Cstock) (Assunção et al., 2019; Falcão et al., 2020). This reduction in C quality and content in systems with soil disturbance occurs mainly due to the exposure of SOM to the direct action of microorganisms, potentiating $\mathrm{C}$ oxidation (Yang et al., 2019; Li et al., 2019).

Systems managed with pastures are important in maintaining soil quality, given the extension of these cultivated areas across the planet (Salton et al., 2008; Santos et al., 2019), especially pastures with adequate management, which present an increase in SOM in surface and subsurface layers due to root decomposition (Coonan et al., 2019; Malcolm et al., 2019). On the other hand, pastures undergoing degradation stages, with low biomass production and soil cover and under the beginning of the emergence of erosive processes, negatively influence soil quality, compromising soil C quality and quantity (Segnini et al., 2019; Zago et al., 2019; Webster et al., 2019).

Thus, the regionalized assessment of soil attributes under different management systems allows identifying management models that contribute significantly to the maintenance or improvements in the quality of the areas, with consequent lesser environmental impacts.

Thus, this study aimed to assess the soil density and the total organic carbon contents and stocks in different management systems under clayey soil in the municipality of Iguatemi, MS, Brazil.

\section{Material and Methods}

\subsection{Location, climate, and soil of study areas}

The experiment was conducted in a native forest area and different management systems exploited commercially in farms located in the municipality of Iguatemi (Figure 1), Southern Cone region of the state of Mato Grosso do Sul, Brazil. The regional climate is subtropical (Cfa), according to the Köppen classification. The native vegetation of the area is the Atlantic Forest, a seasonal semideciduous forest (SEMADE, 2015). The soil is classified as clayey-textured Oxisol (Santos et al., 2018). The studied areas are under the same biome, topography, and soil type and class, and have a particle size distribution at a depth of $0-0.2 \mathrm{~m}$ of 402,96 , and 502 $\mathrm{g} \mathrm{kg}^{-1}$ of clay, silt, and sand, respectively.

Three managed areas and a reference area with native Atlantic Forest vegetation, that is, a seasonal semideciduous forest with no anthropic action, were assessed, totaling four different systems analyzed in a completely randomized design. The three managed areas consisted of a degraded pasture area (DP), a reformed pasture area (RP), and a cultivated area under the conventional tillage system (CT). The description of the areas is shown in Table 1.

\subsection{Soil sample collection}

Four $400 \mathrm{~m}^{2}$ plots were demarcated in each study area, where soil samples were collected, and each plot represented a replication. Each composite sample was represented by five simple samples within each plot at depths of $0-0.05,0.05-0.1$ and $0.1-0.2 \mathrm{~m}$. After collection, the samples were air-dried, crumbled, and sieved ( $2 \mathrm{~mm}$ openings). Undisturbed samples were also collected using a volumetric ring with a volume of 48.86 $\mathrm{cm}^{3}$, with four replications in all areas and soil depths.

\subsection{Soil analyses}

Soil density ( $\mathrm{Sd}$ ) analyses were performed according to the method described by Claessen (1997), using the volumetric ring method. Total organic carbon (TOC) was determined by the oxidation of organic matter by potassium dichromate in sulfuric medium and titrated with ammonium ferrous sulfate in the presence of diphenylamine without external heating, according to a method adapted from Yeomans and Bremner (1988). The results allowed the calculation of the total organic carbon stocks (Cstock), according to the equivalent mass method 
(Ellert and Bettany, 1995; Sisti et al., 2004). The carbon stock variation ( $\Delta$ Cstock) was calculated to verify trends of TOC accumulation or loss in comparison with the reference system (NF).

The TOC results also allowed the calculation of the carbon stratification index (SI) through the ratio between the TOC contents at depths of $0-0.05$ and $0.1-0.2 \mathrm{~m}$ (arable layer), as proposed by Franzluebbers (2002).

After all analyses, the results were analyzed for normality and homogeneity of the data using the
Lilliefors and Cochran and Bartlett tests, respectively. Subsequently, the results were subjected to analysis of variance and the F-test, with the means values compared by the Tukey test at $5 \%$ probability, using the software GENES (Cruz, 2006).

In addition, a principal component analysis (ACP) was generated using the R Core Team program (2019) through the command prcomp from the package vegan (Oksanen et al., 2019), with the variables TOC, Cstock, $\mathrm{Sd}$, and SI.

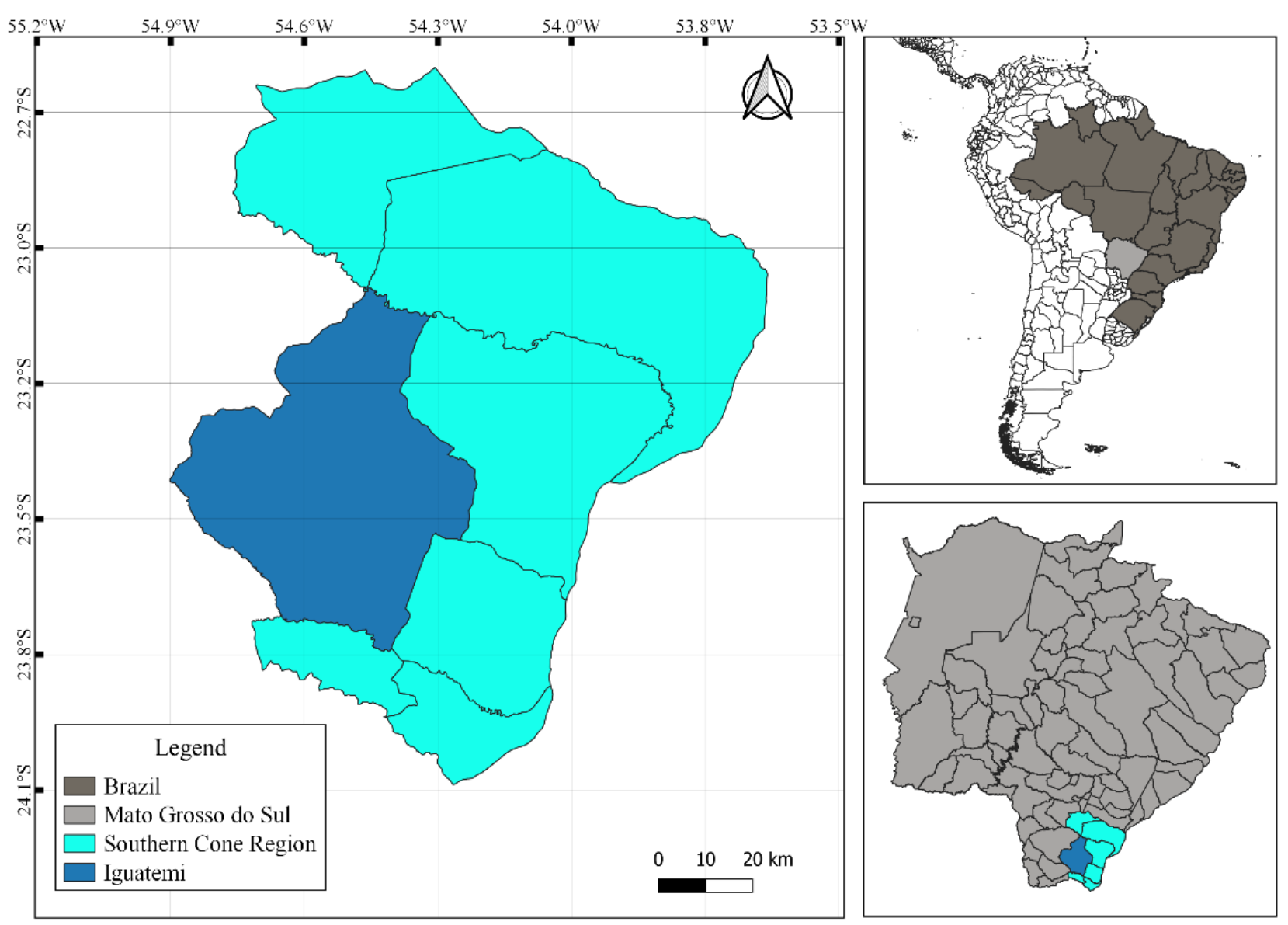

Figure 1. Municipality of Iguatemi, MS, Brazil, where the study areas are located. Mapping software: QGIS 3.14.15 'Pi'.

Table 1. History and description of the study areas (management systems).

\begin{tabular}{ll}
\hline Management system & \multicolumn{1}{c}{ Description } \\
\hline DP & $\begin{array}{l}\text { Area of } 2.0 \text { ha implanted in } 2000 \text { with the species Brachiaria brizantha, with visible signs of } \\
\text { degradation (low soil cover, presence of invasive species and erosions in the form of furrows). } \\
\text { Capacity of } 6 \text { animal units (UA) ha }{ }^{-1} \text {. }\end{array}$ \\
\hline RP & $\begin{array}{l}\text { Area of } 2.0 \text { ha, pasture with the species Brachiaria brizantha, which in 2008 carried out a } \\
\text { reform of the area with soil revolving and application of } 1.5 \text { tons of limestone. Capacity of } 6 \\
\text { animal units (UA) ha }{ }^{-1} \text {. }\end{array}$ \\
\hline CT & $\begin{array}{l}1.7 \text { ha area. Pasture from 1990 until 2010, where the crop was implanted in a conventional } \\
\text { tillage system with annual use of plowing and leveling harrow with alternate crops of corn, } \\
\text { cassava and watermelon. }\end{array}$ \\
\hline NF & $\begin{array}{l}\text { Area of 10.0 ha of legal reserve without any anthropic interference, used as a reference for the } \\
\text { original condition of the soil. }\end{array}$ \\
\hline
\end{tabular}




\section{Results and Discussion}

The NF area showed the lowest SD values, reaching $1.03,1.23$, and $1.26 \mathrm{Mg} \mathrm{m}^{-3}$ at depths of $0-0.05,0.05-$ 0.1 , and $0.1-0.2 \mathrm{~m}$, respectively (Table 2). The lowest $\mathrm{Sd}$ values observed in the NF area occurred because this area has not been subjected to any anthropic action, such as soil tillage and grazing, which are carried out in crop and pasture areas, promoting soil compaction and a consequent decrease in macropores and soil water regulation (Colombi et al., 2018; Felde et al., 2018; Furbish et al., 2018).

All managed areas presented similar $\mathrm{Sd}$ values at depths of $0-0.05$ and $0.1-0.2 \mathrm{~m}$. The TC area showed the highest $\mathrm{Sd}$ value at a depth of $0.05-0.1 \mathrm{~m}$, which was similar to DP (Table 2). The Sd values found in the DP, $\mathrm{RP}$, and CT areas at all depth could compromise the physical soil quality and the root growth of crops when considering the critical value of $1.30 \mathrm{Mg} \mathrm{m}^{-3}$ proposed by Reichert et al. (2003) for clayey soils.

In general, the results of TOC and Cstock showed a similar pattern between the assessed areas. The NF and RP presented the TOC contents at all assessed layers, reaching values of $17.45,9.70$, and $9.70 \mathrm{~g} \mathrm{~kg}^{-1}$ in NF and $14.11,11.18,9.25 \mathrm{~g} \mathrm{~kg}^{-1}$ in RP at depths of $0-0.05,0.05$ 0.1 and $0.1-0.2 \mathrm{~m}$, respectively. The lowest TOC contents were found in the DP and CT areas, reaching $3.39 \mathrm{~g} \mathrm{~kg}^{-1}$ at a depth of $0.1-0.2 \mathrm{~m}$ in DP. In percentage terms, comparing only the pasture areas, DP presented $60.1,38.6$, and $36.7 \%$ of the TOC contents found in RP at depths of $0-0.05,0.05-0.1$ and $0.1-0.2 \mathrm{~m}$, respectively (Table 2).

Table 2. Soil density (Sd), total organic carbon (TOC), and soil carbon stock (Cstock) in different management systems in the municipality of Iguatemi, MS, Brazil.

\begin{tabular}{|c|c|c|c|}
\hline \multirow{3}{*}{ MS } & $\mathrm{Sd}$ & TOC & Cstock \\
\hline & $\mathrm{Mg} \mathrm{m}^{-3}$ & $\mathrm{~g} \mathrm{~kg}^{-1}$ & $\mathrm{Mg} \mathrm{ha}^{-1}$ \\
\hline & \multicolumn{3}{|c|}{$0-0.05 \mathrm{~m}$} \\
\hline $\mathrm{DP}$ & $1.48 \mathrm{a}$ & $8.52 b$ & $4.41 \mathrm{~b}$ \\
\hline RP & $1.34 \mathrm{a}$ & $14.11 \mathrm{a}$ & $7.34 \mathrm{a}$ \\
\hline CT & $1.58 \mathrm{a}$ & $9.31 \mathrm{~b}$ & $4.83 b$ \\
\hline NF & $1.03 \mathrm{~b}$ & $17.45 \mathrm{a}$ & $6.98 \mathrm{a}$ \\
\hline \multirow[t]{2}{*}{$\mathrm{CV}(\%)$} & 8.4 & 13.0 & 17.0 \\
\hline & \multicolumn{3}{|c|}{$0.05-0.1 \mathrm{~m}$} \\
\hline DP & $1.57 \mathrm{ab}$ & $4.31 \mathrm{c}$ & $2.63 \mathrm{c}$ \\
\hline RP & $1.48 \mathrm{~b}$ & $11.18 \mathrm{a}$ & $6.86 \mathrm{a}$ \\
\hline CT & $1.71 \mathrm{a}$ & $9.11 \mathrm{~b}$ & $5.59 \mathrm{~b}$ \\
\hline NF & $1.23 \mathrm{c}$ & 9.70ab & $4.46 \mathrm{~b}$ \\
\hline \multirow[t]{2}{*}{$\mathrm{CV}(\%)$} & 6.3 & 9.3 & 11.4 \\
\hline & \multicolumn{3}{|c|}{$0.1-0.2 \mathrm{~m}$} \\
\hline DP & $1.62 \mathrm{a}$ & $3.39 \mathrm{c}$ & $4.26 \mathrm{c}$ \\
\hline $\mathrm{RP}$ & $1.60 \mathrm{a}$ & $9.25 \mathrm{a}$ & $11.62 \mathrm{a}$ \\
\hline CT & $1.70 \mathrm{a}$ & $7.47 b$ & $9.38 \mathrm{~b}$ \\
\hline $\mathrm{NF}$ & $1.26 \mathrm{~b}$ & $9.70 \mathrm{a}$ & $10.44 a b$ \\
\hline $\mathrm{CV}(\%)$ & 5.7 & 9.8 & 10.2 \\
\hline
\end{tabular}

Means followed by the same letter in the column within each depth do not differ from each other by the Tukey test ( $\mathrm{p} \leq 0.05)$. $\mathrm{CV}=$ coefficient of variation. MS: Management systems; DP: Degraded pasture; RP: Reformed pasture; CT: Conventional tillage system; NF: Native forest.
The Cstock values varied from 2.63 to $11.62 \mathrm{Mg} \mathrm{ha}^{-1}$. Similar Cstock values could be observed between the NF and RP areas at depths of $0-0.05$ and $0.1-0.2 \mathrm{~m}$, with values of 6.98 and $7.34 \mathrm{Mg} \mathrm{ha}^{-1}$, respectively. The Cstock values in the DP area were lower than in RP at all assessed depths, reaching $39.9,61.7$, and $63.3 \%$ of the Cstock at depths of $0-0.05,0.05-0.1$, and $0.1-0.2 \mathrm{~m}$, respectively. The TOC and Cstock contents showed that the CT area was not efficient in accumulating $\mathrm{C}$ in the soil compared to RP, with values of $4.83,5.59$, and 9.38 $\mathrm{Mg} \mathrm{ha}^{-1}$ at depths of $0-0.05,0.05-0.1$, and $0.1-0.2 \mathrm{~m}$ (Table 2).

The results of TOC and Cstock demonstrate the negative impact of incorrect pasture management, in which little vegetation cover limits the SOM entry into the soil (Santos et al., 2019; Segnini et al., 2019; Lopes et al., 2020). Segnini et al. (2019) assessed C loss in pastures under different grazing intensities and reported low TOC contents in degraded pasture areas compared to natural vegetation areas. Pasture systems can benefit $\mathrm{C}$ inputs in the system when properly managed and, consequently, increase Cstock (Salton et al., 2008; Santos et al., 2019; Falcão et al., 2020), favoring the quality of the edaphic environment and contributing to reducing greenhouse gas emissions (Koven et al., 2017).

The annual soil tillage in the CT areas potentiated the rapid SOM decomposition, which does not undergo all the stages of the humification process, with consequent less TOC stabilization, drastically reducing its soil contents (Assunção et al., 2019; Nijmeijer et al., 2019; Sithole et al., 2019). It is mainly due to the intense tillage that occurs in the system for preparing these areas. Soil tillage, besides fragmenting organic compounds by cutting discs, promotes soil breakdown, which accelerates the mineralization processes of SOM (Assunção et al., 2019; Denardin et al., 2019; Macintosh et al., 2019). Comin et al. (2018) reported high Cstock values in native forest areas compared to areas with soil disturbance.

All studied areas presented the stratification index (SI) of TOC higher than one, with values ranging from 1.25 to 2.54 (Figure 2), which indicates $C$ accumulation on the soil surface (Franzluebbers, 2002). The DP area showed the highest SI value (2.54), differing from the other areas. This result is related to the low TOC contents in the DP area at a depth of $0.1-0.2 \mathrm{~m}$ because of the low contribution of the root system in accumulating carbon in the subsurface (Table 2), overestimating the SI values for this area (Figure 2).

The CT and RP areas had the lowest SI values, reaching 1.25 and 1.53 , respectively (Figure 2). The stratification of $\mathrm{C}$ in the soil is desirable, especially for $\mathrm{C}$ storage at deeper subsurface layers (Ozório et al., 2020), favoring the improvement of their quality (Salton et al., 2014). Salton et al. (2014), Ozório et al. (2020), and 
Troian et al. (2020) observed SI values of 2.00, 1.85, and 1.08 , respectively, in areas of permanent pasture in the state of Mato Grosso do Sul. Moreover, Rosset et al. (2014) found a value of 1.78 in a pasture area managed for 38 years in the state of Paraná.

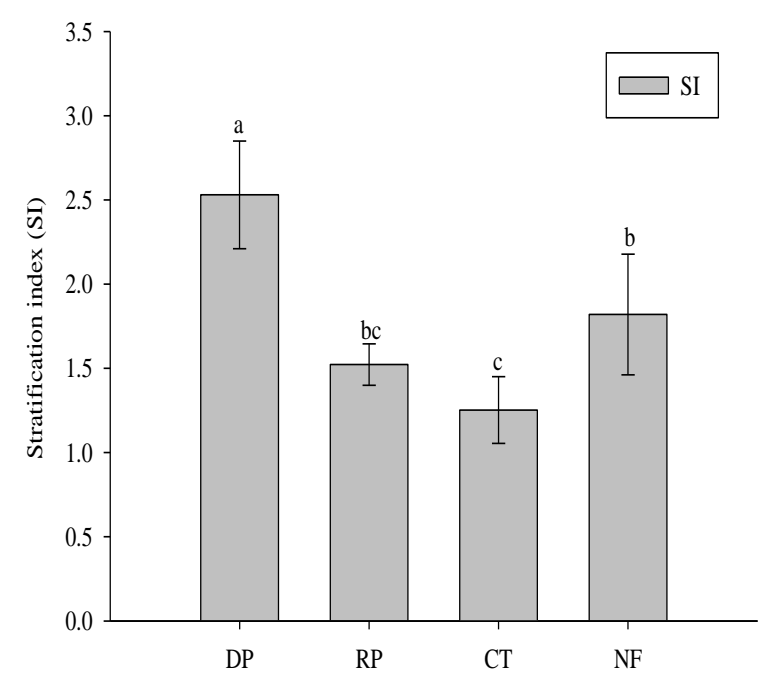

Figure 2. Stratification index (SI) of the total organic carbon as a function of different management systems under a clayey soil. DP: Degraded pasture; RP: Reformed pasture; CT: Conventional tillage system; NF: Native forest.

Negative $\Delta$ Cstock values were observed at all assessed depths in the DP area (Figure 3), which is in accordance with the low Cstock contents of this area (Table 2). Proper management of pasture areas is essential for the maintenance and improvement of carbon stocks, with consequent improvements in other soil attributes (Ozório et al., 2020; Rosset et al., 2019; Ferreira et al., 2020). Mascarenhas et al. (2017) and Oliveira et al. (2016) reported that the conversion of native areas into pasture systems could significantly compromise the carbon stocks when not managed correctly, mainly due to the low deposition of organic matter on the soil.

The soil depths of $0-0.05$ and $0.1-0.2 \mathrm{~m}$ in the CT area showed negative $\Delta$ Cstock compared to the NF area. However, the $\Delta$ Cstock of the RP area was positive at all depths (Figure 3 ), which proves the importance of good management of these areas to increase $\mathrm{C}$ storage potential and, consequently, decrease $\mathrm{CO}_{2}$ emissions into the atmosphere (Salton et al., 2008; Assunção et al., 2019).

A negative Cstock variation was observed in the entire studied soil profile $(0-0.2 \mathrm{~m})$, that is, the three stratified soil layers together, for the CT area and, more accentuated, in the DP area, differently from that observed in RP (Figure 3). The evaluation of changes that have occurred in edaphic attributes due to their use and management is of great practical importance since understanding the changes that have occurred in the most sensitive attributes, such as Cstock, could provide elements for sustainable production (Oliveira et al., 2016). Comin et al. (2018) observed similar results, i.e., a system with annual tillage showed lower Cstock values in the arable layer than native forest and production systems without soil disturbance.

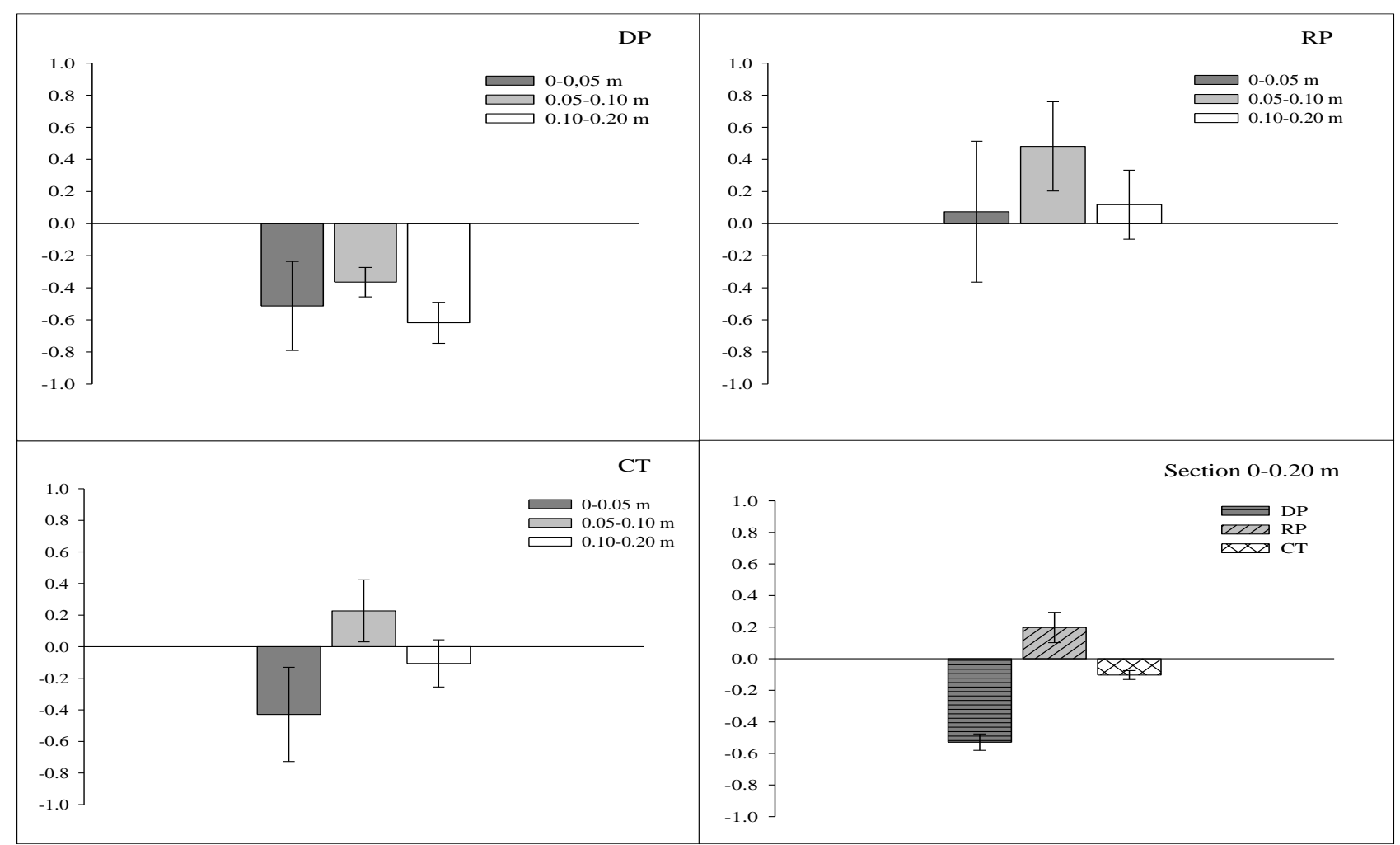

Figure 3. Variation in TOC stock ( $\triangle$ Cstock) of the managed areas relative to the native forest area at different soil depths and in the 0-0.2 m layer of clayey soil. DP: Degraded pasture; RP: Reformed pasture; CT: Conventional tillage system. 
Figure 4 shows the principal component analysis involving the variables Sd, TOC, Cstock, and SI under the different assessed management systems. The variation in axis 1 explains $57.0 \%$ of the total variation in the data. This axis separated the NF and RP areas, with positive values, from CT and DP, which had negative values. TOC and Cstock contents at a depth of $0-0.05 \mathrm{~m}$ were positively correlated in the NF area (Figure 4). It occurs because TOC and Cstock contents at the first soil depth were high due to an intense SOM deposition and the non-soil tillage, allowing the process of humification and accumulation of stabilized organic matter (Lal, 2018; Signor et al., 2018; Assunção et al., 2019).

The values of TOC and Cstock of the subsurface depths (0.05-0.1 and 0.1-0.2 m) were also similar in the $\mathrm{RP}$ and NF areas (Figure 4). It shows the potential for C stratification in the soil profile, which is of paramount importance, mainly in improving soil quality and storing $\mathrm{C}$ in layers with less interference of soil management (Borges et al., 2015; Muñoz-Rojas et al., 2015). The ability of well-managed pastures to store $C$ in subsurface layers has been reported by different authors in different Brazilian biomes (Salton et al., 2008; Dortzbach et al., 2015; Mascarenhas et al., 2017; Santos et al., 2017; Campos et al., 2016). On the other hand, $\mathrm{Sd}$ is mainly associated with the CT area (Figure 4), which is in line with the highest $\mathrm{Sd}$ values observed in this area (Table 2). It occurs because of the management of the area using the conventional tillage system, with an intense traffic of agricultural machinery (Gennaro et al., 2015). Loss et al. (2017) worked with the conventional tillage and notillage systems and observed high Sd values in the CT area, which was attributed to the process of intense soil disturbance.

The data assessment allowed verifying the importance of proper soil management, as well as continuous studies that assess their influence on soil quality. This study provided technical information applicable in different regions due to the characteristics of the assessed soil type and systems.

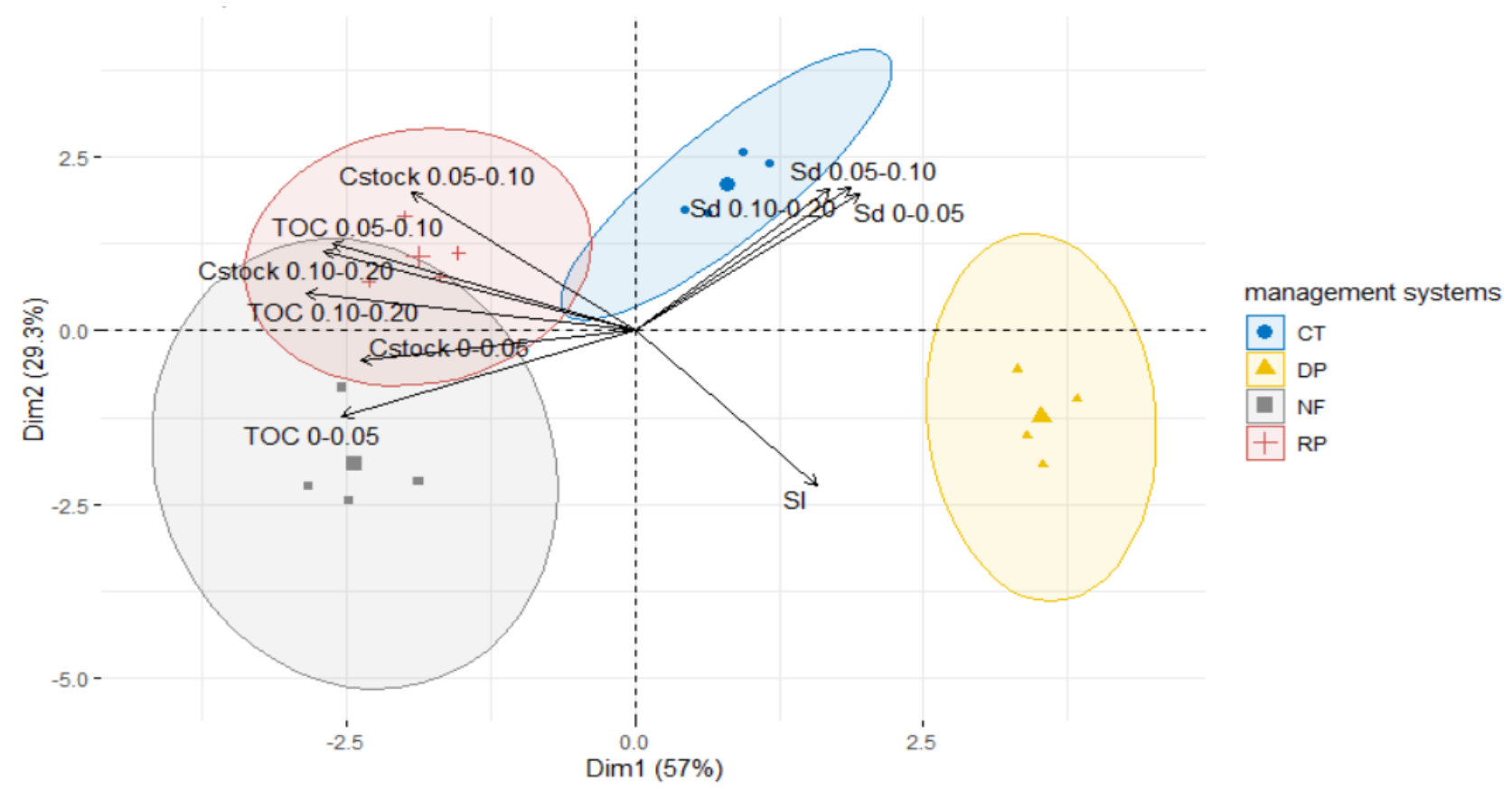

Figure 4. Principal component analysis of TOC, Cstock, Sd, and SI in different management systems: DP: Degraded pasture; RP: Reformed pasture; CT: Conventional tillage system; NF: Native forest.

\section{Conclusions}

All managed areas had the highest soil density at the three assessed soil depths.

The reformed pasture area showed the same carbon storage potential compared to the native forest area.

The degraded pasture and conventional tillage areas compromised edaphic quality, especially regarding the carbon storage potential.

The principal component analysis showed that the reformed pasture area was similar to the native forest area.

\section{Acknowledgments}

We thank Fundect (Fundect/UEMS Notice No. $25 / 2015$ ) for supporting the undergraduate and graduate courses at UEMS; the PIBIC/UEMS notice for granting a scientific initiation scholarship to the undergraduate students; the Coordination for the Improvement of Higher Education Personnel (CAPES) for granting a Postgraduate scholarship; and the farmers for allowing this study to be developed in their areas. 


\section{Bibliographic References}

Assunção, S.A., Pereira, M.G., Rosset, J.S., Berbara, R.L.L., García, A.C., 2019. Carbon input and the structural quality of soil organic matter as a function of agricultural management in a tropical climate region of Brazil. Science of The Total Environment, 658, 901-911. DOI: https://doi.org/10.1016/j.scitotenv.2018.12.271.

Borges, C.S., Ribeiro, B.T., Wendling, B., Cabral, D.A., 2015. Agregação do solo, carbono orgânico e emissão de CO2 em áreas sob diferentes usos no Cerrado, região do Triângulo Mineiro. Revista Ambiente \& Água, 10(3), 660-675. DOI: http://dx.doi.org/10.4136/ambi-agua.1573.

Campos, M.C.C., Soares, M.D.R., Nascimento, M.F., Marcelo, D., Silva, P., 2016. Estoque de carbono no solo e agregados em Cambissolo sob diferentes manejos no sul do Amazonas. Ambiente \& Água, 11(2), 339-349. DOI: 10.4136/ambiagua.1819.

Claessen, M.E.C., 1997. Manual de métodos de análise de solo, segunda ed. Rio de Janeiro, Embrapa.

Colombi, T., Torres, L.C., Walter, A., Keller, T., 2018. Feedbacks between soil penetration resistance, root architecture and water uptake limit water accessibility and crop growth - A vicious circle. Science of the Total Environment, 626, 10261035. DOI: https://doi.org/10.1016/j.scitotenv.2018.01.129.

Comin, J.J., Ferreira, L.B., Santos, L.H., Koucher, L.P., Machado, L.N., Santos Junior, E., Mafra, A.L., Kurtz, C., Souza, M., Brunetto, G, Loss, A., 2018. Carbon and nitrogen contents and aggregation index of soil cultivated with onion for seven years using crop successions and rotations. Soil and Tillage Research, 184, 195-202. DOI: https://doi.org/10.1016/j.still.2018.08.002.

Coonan, E.C., Richardson, A.E., Kirkby, C.A., Kirkegaard, J.A., Amidy, M.R., Simpson, R.J., Strong, C.L., 2019. Soil carbon sequestration to depth in response to long-term phosphorus fertilization of grazed pasture. Geoderma, 338, 226-235.

https://doi.org/10.1016/j.geoderma.2018.11.052.

Corbeels, M., Cardinael, R., Naudin, K., Guibert, H., Torquebiau, E., 2019. The 4 per 1000 goal and soil carbon storage under agroforestry and conservation agriculture systems in sub-Saharan Africa. Soil and Tillage Research, 188, 16-26. DOI: https://doi.org/10.1016/j.still.2018.02.015.

Cruz, C.D., 2006. Programa genes: biometria. Viçosa, UFV.

D’Abadia, K.L., Souza, A.G.V., Machado, M.S., Santos, T.E.B., 2020. Hydro-microbiological attributes of the soil in edge of seasonal semideciduous forest fragment. Journal of Neotropical Agriculture, 7(1), 18-24. DOI: https://doi.org/10.32404/rean.v7i1.3919.

Denardin, L.G.D.O., Carmona, F.D.C., Veloso, M.G., Martins, A.P., Freitas, T.F.S., Carlos, F.S., Marcolin, E., Camargo, F.A.O., Anghinoni, I., 2019. No-tillage increases irrigated rice yield through soil quality improvement along time. Soil and Tillage Research, 186, 64-69. DOI: https://doi.org/10.1016/j.still.2018.10.006.

Doran, J.W., Parkin, T.B., 1994. Defining and assessing soil quality, in: Doran, J.W., Coleman, D.C., Bezdicek, D.F.,
Stewart, B.A., (Eds.). Defining soil quality for a sustainable environment. Soil Science Society of America Journal, $\begin{array}{llll}\text { Madison, } & \text { p. } & 3-21 . & \text { DOI: }\end{array}$ http://dx.doi.org/10.2136/sssaspecpub35.c1.

Dortzbach, D., Pereira, M.G., Blainski, É., González, A.P., 2015. Estoque de C e abundância natural de $13 \mathrm{C}$ em razão da conversão de áreas de floresta e pastagem em bioma Mata Atlântica. Revista Brasileira de Ciência do Solo, 39(6), 16431660. DOI: https://doi.org/10.1590/01000683rbcs20140531.

Ellert, B.H., Bettany, J.R., 1995. Calculation of organic matter and nutrients stored in soils under contrasting management regimes. Canadian Journal of Soil Science, 75(4), 529-538. DOI: https://doi.org/10.4141/cjss95-075.

Falcão, K.S., Monteiro, F.N., Ozório, J.M.B., Souza, C.B.S., Farias, P.G.S., Menezes, R.S., Panachuki, E., Rosset, J.S., 2020. Estoque de carbono e agregação do solo sob diferentes sistemas de uso no Cerrado. Revista Brasileira de Ciências Ambientais (Online), 55(2), 242-255. DOI: 10.5327/Z2176-947820200695.

Felde, V.J., Drahorad, S.L., Felix-Henningsen, P., Hoon, S.R., 2018. Ongoing oversanding induces biological soil crust layering - A new approach for biological soil crust structure elucidation determined from high resolution penetration resistance data. Geoderma, 313, 250-264. DOI: https://doi.org/10.1016/j.geoderma.2017.11.022.

Ferreira, C.R., Neto, E.C.S., Pereira, M.G., Guedes, J.N., Rosset, J.S., Anjos, L.H.C., 2020. Dynamics of soil aggregation and organic carbon fractions over 23 years of no-till management. Soil and Tillage Research, 198, 104533. DOI: https://doi.org/10.1016/j.still.2019.104533.

Franzluebbers, A.J., 2002. Soil organic matter stratification ratio as an indicator of soil quality. Soil and Tillage Research, 66(2), 95-106. DOI: https://doi.org/10.1016/S01671987(02)00018-1.

Furbish, D.J., Roering, J.J., Almond, P., Doane, T.H., 2018. Soil particle transport and mixing near a hillslope crest: 1 . Particle ages and residence times. Journal of Geophysical Research: Earth Surface, 123(5), 1052-1077. DOI: https://doi.org/10.1029/2017JF004315.

Gennaro, L.A.D., Souza, Z.M.D., Silva, L.F.S.D., Cooper, M., Campos, M.C.C., 2015. Estrutura do solo sob feijão irrigado e diferentes manejo do solo. Revista Brasileira de Ciência do Solo, 39(2), 608-614. http://dx.doi.org/10.1590/01000683rbcs20140441.

Koven, C.D., Hugelius, G., Lawrence, D.M., Wieder, W.R., 2017. Higher climatological temperature sensitivity of soil carbon in cold than warm climates. Nature Climate Change, 7(11), 817-822. DOI: https://doi.org/10.1038/nclimate3421.

Lal, R., 2018. Digging deeper: A holistic perspective of factors affecting soil organic carbon sequestration in agroecosystems. Global Change Biology, 24(8), 3285-3301. DOI: https://doi.org/10.1111/gcb.14054.

Li, P., Shi, K., Wang, Y., Kong, D., Liu, T., Jiao, J., Liu, M, Huixin, L., Hu, F., 2019. Soil quality assessment of wheatmaize cropping system with different productivities in China: Establishing a minimum data set. Soil and Tillage Research, 190, 31-40. DOI: https://doi.org/10.1016/j.still.2019.02.019. 
Lopes, V.S., Cardoso, I.M., Fernandes, O.R., Rocha, G.C., Simas, F.N.B., Moura, W.M., Santana, F.C., Veloso, G.V., Luz, J.M.R., 2020. The establishment of a secondary forest in a degraded pasture to improve hydraulic properties of the soil. Soil and Tillage Research, 198, 1-9. DOI: https://doi.org/10.1016/j.still.2019.104538.

Loss, A., Santos Junior, E., Schmitz, D., Veiga, M., Kurtz, C., Comin, J.J., 2017. Atributos físicos do solo em cultivo de cebola sob sistemas de plantio direto e preparo convencional. Revista Colombiana de Ciencias Hortícolas, 11(1), 105-113. DOI: https://doi.org/10.17584/rcch.2017v11i1.6144.

Macintosh, K.A., Doody, D.G., Withers, P.J., Mcdowell, R.W., Smith, D.R., Johnson, L.T., Bruulsema, T.W., O`flaherty, V., Mcgrath, J.W., 2019. Transforming soil phosphorus fertility management strategies to support the delivery of multiple ecosystem services from agricultural systems. Science of the Total Environment, 649, 90-98. DOI: https://doi.org/10.1016/j.scitotenv.2018.08.272.

Malcolm, B.J., Cameron, K.C., Curtin, D., Di, H.J., Beare, M.H., Johnstone, P.R., Edwards, G.R., 2019. Organic matter amendments to soil can reduce nitrate leaching losses from livestock urine under simulated fodder beet grazing. Agriculture, Ecosystems \& Environment, 272, 10-18. DOI: https://doi.org/10.1016/j.agee.2018.11.003.

Mascarenhas, A.R.P., Sccoti, M.S.V., Melo, R.R., Corrêa, F.L.O., Souza, E.F.M., Andrade, R.A., Bergamin, A.C., Müller, M.W., 2017. Atributos físicos e estoques de carbono do solo sob diferentes usos da terra em Rondônia, Amazônia SulOcidental. Pesquisa Florestal Brasileira, 37(89), 19-27. DOI: 10.4336/2017.pfb.37.89.1295.

Muñoz-Rojas, M., Jordán, A., Zavala, L.M., De la Rosa, D., Abd-Elmabod, S.K., Anaya-Romero, M., 2015. Impact of land use and land cover changes on organic carbon stocks in Mediterranean soils (1956-2007). Land Degradation \& $\begin{array}{llll}\text { Development, } & 26(2), & 168-179 . & \text { DOI: }\end{array}$ https://doi.org/10.1002/ldr.2194.

Nijmeijer, A., Lauri, P.É., Harmand, J.M., Saj, S., 2019. Carbon dynamics in cocoa agroforestry systems in Central Cameroon: afforestation of savannah as a sequestration opportunity. Agroforestry Systems, 93(3), 851-868. DOI: https://doi.org/10.1007/s10457-018-0204-z.

Oksanen, J.F., Blanchet, G., Friendly, M., Kindt, R., Legendre, P., Mcglinn, D., Minchin, P.R., O’hara, R.B., Simpson, G.L., Solymos, P., Stevens, M.H.H., Szoecs, E., Wagner, H., 2019. Vegan: Community Ecology Package. R Package Version 2.55. https://CRAN.R-project.org/package=vegan (Accessed January 10, 2020).

Oliveira, W.R.D., Ramos, M.L.G., Carvalho, A.M., Coser, T.R., Silva, A.M.M., Lacerda, M.M., Souza, K.W., Marchão, R.L., Vilela, L., Pulrolnik, K., 2016. Dynamics of soil microbiological attributes under integrated production systems, continuous pasture, and native Cerrado. Pesquisa Agropecuária Brasileira, 51(9), 1501-1510. DOI: http://dx.doi.org/10.1590/s0100-204x2016000900049.

Ozório, J.M.B., Rosset, J.S., Schiavo, J.A., Panachuki, E., Souza, C.B.S., Menezes, R.S., Castilho, S.C.P, Marra, L.M., 2020. Estoque de carbono e agregação do solo sob fragmentos florestais nos biomas Mata Atlântica e Cerrado. Revista
Brasileira de Ciências Ambientais (Online), 53, 97-116. DOI: 10.5327/Z2176-947820190518.

R Core Team, 2019. R: A language and environment for statistical computing. R Foundation for Statistical Computing, Vienna, Austria. https://www.R-project.org/ (Accessed July 12, 2020).

Reichert, J.M., Reinert, D.J., Braida, J.A., 2003. Qualidade dos solos e sustentabilidade de sistemas agrícolas. Ciência \& Ambiente, 27, 29-48.

Rosset, J.S., Lana, M.C., Pereira, M.G., Schiavo, J.A., Rampim, L., Sarto, M.V.M., 2016. Frações químicas e oxidáveis da matéria orgânica do solo sob diferentes sistemas de manejo, em Latossolo Vermelho. Pesquisa Agropecuária Brasileira, 51(9), 1529-1538. DOI: https://doi.org/10.1590/s0100$204 \times 2016000900052$.

Rosset, J.S., Lana, M.C., Pereira, M.G., Schiavo, J.A., Rampim, L., Sarto, M.V.M., 2019. Organic matter and soil aggregation in agricultural systems with different adoption times. Semina: Ciências Agrárias, 40(6), 3443-3460. DOI: 10.5433/16790359.2019v40n6Supl3p3443.

Rosset, J.S., Lana, M.C., Pereira, M.G., Schiavo, J.A., Rampim, L., Sarto, M.V.M., Seidel, E.P., 2014. Carbon stock, chemical and physical properties of soils under management systems with different deployment times in western region of Paraná, Brazil. Semina: Ciências Agrárias, 35(6), 3053-3072. DOI: 10.5433/1679-0359.2014v35n6p3053.

Salton, J.C., Mercante, F.M., Tomazi, M., Zanatta, J.A., Concenço, G., Silva, W.M., Retore, M., 2014. Integrated croplivestock system in tropical Brazil: Toward a sustainable production system. Agriculture, Ecosystems \& Environment, 190, 70-79. DOI: https://doi.org/10.1016/j.agee.2013.09.023.

Salton, J.C., Mielniczuk, J., Bayer, C., Boeni, M., Conceição, P.C., Fabrício, A.C., Macedo, M.C.M., Broch, D.L., 2008. Agregação e estabilidade de agregados do solo em sistemas agropecuários em Mato Grosso do Sul. Revista Brasileira de Ciência do Solo, 32(1), 11-21. DOI: https://doi.org/10.1590/S0100-06832008000100002.

Santos, C.A., Rezende, C.D.P., Pinheiro, É.F.M., Pereira, J.M., Alves, B.J., Urquiaga, S., Boddey, R.M., 2019. Changes in soil carbon stocks after land-use change from native vegetation to pastures in the Atlantic forest region of Brazil. Geoderma, 337, 394-401.

https://doi.org/10.1016/j.geoderma.2018.09.045.

Santos, F.A.S., Pierangeli, M.A.P., Silva, F.L., Serafim, M.E., Sousa, J.B., Oliveira, E.B., 2017. Dinâmica do carbono orgânico de solos sob pastagens em campos de murundus. Scientia Agraria, 18(2), 43-53. DOI: https://www.redalyc.org/articulo.oa?id=99551919005.

Santos, H.G., Jacomine, P.K.T., Anjos, L.H.C., Oliveira, V.A., Lumbreras, J.F., Coelho, M.R., Almeida, J.A., Araújo Filho, J.C., Oliveira, J.B., Cunha, T.J.F., 2018. Sistema Brasileiro de Classificação de Solos, quinta ed. Brasília, Embrapa, 356 p.

Sarker, T.C., Incerti, G., Spaccini, R., Piccolo, A., Mazzoleni, S., Bonanomi, G., 2018. Linking organic matter chemistry with soil aggregate stability: Insight from 13C NMR spectroscopy. Soil Biology and Biochemistry, 117, 175-184. DOI: https://doi.org/10.1016/j.soilbio.2017.11.011. 
Segnini, A., Xavier, A.A.P., Otaviani-Junior, P.L., Oliveira, P.P.A., Pedroso, A.D.F., Praes, M.F.F.M., Rodrigues, P.H.M., Milori, D.M.B.P., 2019. Soil carbon stock and humification in pastures under different levels of intensification in Brazil. Scientia Agricola, 76(1), 33-40. DOI: https://doi.org/10.1590/1678-992x-2017-0131.

SEMADE. Secretaria de Estado de Meio Ambiente e Desenvolvimento Econômico, 2015. Estudo da Dimensão Territorial do Estado de Mato Grosso do Sul: Regiões de Planejamento. Campo Grande, Governo do Estado de Mato Grosso do Sul, 91 p.

Signor, D., Deon, M.D.I., Camargo, P.B.D., Cerri, C.E.P., 2018. Quantity and quality of soil organic matter as a sustainability index under different land uses in Eastern Amazon. Scientia Agricola, 75(3), 225-232. DOI: https://doi.org/10.1590/1678-992x-2016-0089.

Sisti, C.P., Santos, H.P., Kohhann, R., Alves, B.J., Urquiaga, S., Boddey, R.M., 2004. Change in carbon and nitrogen stocks in soil under 13 years of conventional or zero tillage in southern Brazil. Soil and Tillage Research, 76(1), 39-58. DOI: https://doi.org/10.1016/j.still.2003.08.007.

Sithole, N.J., Magwaza, L.S., Thibaud, G.R., 2019. Long-term impact of no-till conservation agriculture and $\mathrm{N}$-fertilizer on soil aggregate stability, infiltration and distribution of $\mathrm{C}$ in different size fractions. Soil and Tillage Research, 190, 147156. DOI: https://doi.org/10.1016/j.still.2019.03.004.

Troian, D., Rosset, J.S., Martins, L.F.B.N., Ozório, J.M.B., Castilho, S.C.P., Marra, L.M., 2020. Carbono orgânico e estoque de carbono do solo em diferentes sistemas de manejo. Revista em Agronegócio e Meio Ambiente, 13, 1447-1469. DOI: https://doi.org/10.17765/2176-9168.2020v13n4p14471469.

Wang, D., Li, C., Parikh, S.J., Scow, K.M., 2019. Impact of biochar on water retention of two agricultural soils - A multiscale analysis. Geoderma, 340, 185-191. DOI: https://doi.org/10.1016/j.geoderma.2019.01.012.

Webster, E., Gaudin, A.C., Pulleman, M., Siles, P., Fonte, S.J., 2019. Improved Pastures Support Early Indicators of Soil Restoration in Low-input Agroecosystems of Nicaragua. Environmental Management, 64(2), 201-212. DOI: https://doi.org/10.1007/s00267-019-01181-8.

Yang, X., Tsibart, A., Nam, H., Hur, J., El-Naggar, A., Tack, F.M.G., Wang, C., Lee, Y.H., Tsang, D.C.W., Ok, Y.S., 2019. Effect of gasification biochar application on soil quality: Trace metal behavior, microbial community, and soil dissolved organic matter. Journal of Hazardous Materials, 365, 684-694. DOI: https://doi.org/10.1016/j.jhazmat.2018.11.042.

Yeomans, J.C., Bremner, J.M., 1988. A rapid and precise method for routine determination of organic carbon in soil. Communications in soil science and plant analysis, 19(13), 1467-1476.

DOI: https://doi.org/10.1080/00103628809368027.

Zago, L.M.S., Ramalho, W.P., Caramori, S., 2019. Does CropLivestock-Forest Systems Contribute to Soil Quality in Brazilian Savannas? Floresta e Ambiente, 26(3), 1-10. DOI: https://doi.org/10.1590/2179-8087.034318. 